\title{
PROMOTING KERATINASE ACTIVITY FROM NEWLY IDENTIFIED STRAIN Strenotrophomonas maltophilia B6 THROUGH OPTIMIZATION AND CHARACTERIZATION
}

\author{
JENDRI MAMANGKEY ${ }^{1}$, DWI SURYANTO ${ }^{1 *}$, ERMAN MUNIR ${ }^{1}$ and \\ APON ZAENAL MUSTOPA ${ }^{2}$ \\ ${ }^{1}$ Department of Biology, Faculty of Mathematics and Natural Sciences, \\ Universitas Sumatera Utara, Medan 20155, Indonesia \\ ${ }^{2}$ Research Centre for Biotechnology, Indonesian Institute of Science (LIPI) Bogor, Indonesia \\ *E-mail:dwisuryanto@usu.ac.id
}

Accepted 30 March 2020, Published online 30 June 2020

\begin{abstract}
Strenotrophomonas maltophilia B6 was a newly identified keratinolytic bacteria isolated from a landfill in North Sumatra. Keratinolytic activitiy of this strain was investigated through optimization and characterization of its enzymatic properties. Amino acid profiles were quantified using High Performance Liquid Chromatography (HPLC) after a 96-h of incubation resulted in $2.2569 \mathrm{mg} \mathrm{mL}^{-1}$ amino acids from a $40-\mathrm{mL}$ fermentation supplemented with $10 \mathrm{~g} / \mathrm{L}$ chicken feathers. The keratinolytic activities were enhanced through addition of $1 \%$ glucose yielded $67.41 \pm 1.1 \mathrm{UmL}^{-1}$ and $0.5 \%$ peptone yielded $90.24 \pm 0.7 \mathrm{UmL}^{-1}$. Keratinolytic activity enhanced with the addition of $\mathrm{Ca}^{+}(116 \%), \mathrm{Na}^{+}(111 \%), \mathrm{Mg}^{+}(110 \%)$ at $10 \mathrm{mM}$ concentration. Zymogram analysis showed a protein band in the $26 \mathrm{kDa}$ of molecular mass, similar to serine protease. Physical and chemical characteristics of degradation products were analyzed using Scanning Electron Microscope (SEM) and Fourier Transform Infra Red (FTIR). Qualitatively, the optimum activity occurred at 96-h of incubation through SEM image analysis. The FTIR peaks detected were peak $3747 \mathrm{~cm}^{-1}(-\mathrm{OH})$; peak $2972 \mathrm{~cm}^{-1}$ (asymmetric -CH3); peak $1641 \mathrm{~cm}^{-1}$ (amide I); peak $1438 \mathrm{~cm}^{-1}$ (amide II); peak $1092 \mathrm{~cm}^{-1}$ (-C-C-); peak $523 \mathrm{~cm}^{-1}$ (-S-S-). Thus, Strenotrophomonas maltophilia B6 may be used as potential biodegradative bacterium to chicken feather wastes in nature.
\end{abstract}

Key words: Feather waste, keratinase, serine protease, Strenotrophomonas maltophilia

\section{INTRODUCTION}

Chicken feather waste is produced in large number as by-product of poultry processing industry which is also the source of pure keratin protein. The research conducted by Wang and Parsons (1997) reported that the protein meal content of poultry feather is $880.0 \mathrm{~g} \mathrm{~kg}^{-1}$. It is estimated that almost 24 billion chickens are slaughtered every year resulting in the increase of feather waste production amounted to 4 billion $\mathrm{kg}$ (Revathi et al., 2013). The poultry feather waste is difficult to be degraded causing contamination to the environment. The wastes stored in the garbage dump, will be buried in the soil leading to a disruption of the balance of soil microbiota ecosystem. The unfinished degradation of feather waste is due to its natural

\footnotetext{
* To whom correspondence should be addressed.
}

structure, keratin dense and stable polypeptides (Brandelli et al., 2010). Keratin is a structural protein resistant to both chemical and physical environmental factors (Anitha \& Palanivelu, 2012; Sivakumar et al., 2012). Protein is also insoluble in acidic and weak in alkaline water.

Keratin is hardly digested by enzyme such as trypsin, pepsin, or papain (Sivakumar et al., 2012; Gradisar et al., 2005). The difficulty to degrade the keratin is due to the high number of hydrogen bonds, hydrophobic interactions, and disulphide bonds (Brandelli et al., 2010). Keratin is mostly found in poultry's feather, wool, horn, nail, claw, beak and hair (Anitha \& Palanivelu, 2012; Sivakumar et al., 2012). The presence of indigenous bacteria in the nature can help the process of keratin degradation of the feather by utilizing the specific protease enzyme (keratinase). In fact, bacterialproduced keratinase plays an important role for 
many applications such as bio fertilizer, leather manufacturing industry, high nutrition fodder, detergent, bio hydrogen production, textile industry and prion hydrolysis (Gupta \& Ramnani, 2006; Brandelli, 2008). The selection of diversity of keratinolytic bacteria is carried out in order to obtain the potential bacteria. Based on the previous research results, it has been found that the bacteria producing the keratinase derived from Gram-positive bacteria (Daroit et al., 2009; Bach et al., 2011a) and Gram-negative bacteria (Bach et al., 2011b; Yamamura et al., 2002; Riffel \& Brandelli, 2006).

Keratinolytic bacteria have been widely documented from Gram-positive strains, especially those capable of degrading $\beta$-keratin, substrate including the chicken feather (Daroit et al., 2009; Bach et al., 2011a; Tork et al., 2013). Extensive protease diversity is very contradictory with the previous application. This is due to the different physiological nature of the bacteria in every place. This interest has brought the researchers around the world to try to exploit the specific possessed characters and the application of the biotechnology (Rao et al., 1998; Gupta et al., 2002). Now, fewer application of keratinase becomes an important concern to isolate the novel of keratinase bacteria from various sources. The application of biotechnology products is supported by biodiversity of the keratinolytic bacteria. The different characters of each enzyme follow the diversity of keratinase bacteria. The cause of these character differences was influenced by the source of bacterial habitat, in other words, the living habitat of keratinolytic bacteria affects the keratinase variation.

The previous research has reported several strains of Stenotrophomonas maltophilia, which can produce keratinase (Fang et al., 2013; Jankiewicz et al., 2016; Jeong et al., 2010; Jankiewicz \& Frąk, 2017; Cao et al., 2009). Different sources of isolation cause the variation of biochemistry. In addition to keratinase-related information, the isolation result of the flue liquid was selected to characterize its keratinase, of which 16S rRNA has been found as Stenotrophomonas maltophilia B6. Our study has characterized keratinase activity against the differences of temperature, $\mathrm{pH}$ and percentage of precipitation with ammonium sulfate (Suryanto et al., 2017). In order to evaluate the enzyme characteristics from strain B6, the aim of the present study is to investigate the optimization condition of different sources of carbon and nitrogen on the production media for the secretion of thermostable keratinase proteases and characterize the native enzymes.

\section{MATERIALS AND METHODS}

\section{Bacterial strain and culture condition}

Keratinolytic bacteria have been isolated previously from a landfill soil in North Sumatra. The proteolytic potential has been selected through the formation of halo zone in skim milk agar media and its ability to degrade the chicken feathers. Strain B6 was closely related to $S$. maltophilia strain BIW based on 16S rRNA genetic similarity. Strain B6 was the source of keratinases in the present study. The isolation sub-cultured on the feather meal agar (FMA) media, contains $15 \mathrm{~g} \mathrm{~L}^{-1}$ of feather meal broth (FMB), 0,5 $\mathrm{g} \mathrm{L}^{-1} \mathrm{NaCl}, 0,7 \mathrm{~g} \mathrm{~L}^{-1} \mathrm{~K}_{2} \mathrm{HPO}_{4}$, $0,4 \mathrm{~g} \mathrm{~L}^{-1} \mathrm{KH}_{2} \mathrm{PO}_{4}, 0,1 \mathrm{~g} \mathrm{~L}^{-1} \mathrm{MgSO}_{4}$ and $15 \mathrm{~g} \mathrm{~L}^{-1}$ agar (Cai et al., 2008). FMB was prepared in the same way as FMA without adding the agar. Skim milk powder (Oxoid) was also prepared with NB agar composition added by $1 \%$ of skim milk powder. All of cultivated media was autoclaved at $121^{\circ} \mathrm{C}, 1 \mathrm{~atm}$ for 15 minutes and cultivated at $37^{\circ} \mathrm{C}$ with rotary shaking at $180 \mathrm{rpm}$. The chicken feathers waste is obtained from the chicken slaughterhouses and washed using water until it was clean completely and ended by ablution using aquadest. Then, the feathers were cut into small fragments $( \pm 2 \mathrm{~cm})$. The pieces of feathers were washed with water and detergent and then soaked with acetone for $24 \mathrm{~h}$. The feather pieces were then heated in oven at $40^{\circ} \mathrm{C}$ for $72 \mathrm{~h}$.

\section{Optimization of fermentation medium}

The growth media was added by carbon sources such as sucrose, fructose, lactose, sorbitol, glucose, and starch (1\%). pH and temperature were adjusted according to keratinase activity studied previously (Suryanto et al., 2017), where controls were production media without carbon source. Different sources of nitrogen include yeast extract, peptone, casein, tryptone, $\mathrm{NaNO}_{3}, \mathrm{KNO}_{3}$, and gelatin $(0.5 \%)$ mixed in a production media with $1 \%$ glucose used as the best additive for keratinase activity. The provision of carbon and nitrogen sources to measure the keratinase activity at different incubation time intervals include $24,48,72,96$, 120, 144 and $168 \mathrm{~h}$.

\section{Production of crude keratinase}

Erlenmeyer containing $50 \mathrm{ml}$ FMB was inoculated in each isolation and incubated at $30^{\circ} \mathrm{C}$ in orbital shaker $(150 \mathrm{rpm})$. After $24 \mathrm{~h}, 5 \%$ $(\mathrm{v} / \mathrm{v})$ inoculum $\left(10^{8} \mathrm{CFU} \mathrm{ml^{-1 }}\right)$ was added into 150 $\mathrm{ml} \mathrm{FMB} \mathrm{and} \mathrm{incubated} \mathrm{under} \mathrm{the} \mathrm{same} \mathrm{condition}$ (Bach et al., 2011b) for 4 days (bacterial logarithm phase). Keratinase was harvested by centrifugation 
of bacterial culture at $8000 \mathrm{X} g$ for 20 minutes at $4^{\circ} \mathrm{C}$. Supernatant was precipitated using ammonium sulfate $70 \%$ (Suryanto et al., 2017) slowly at $\pm 5^{\circ} \mathrm{C}$ evenly. The precipitated result was kept overnight (to maximize the precipitation). The precipitated supernatant was centrifuged on $8000 \mathrm{X} g$ for 20 minutes at $4{ }^{\circ} \mathrm{C}$. The centrifugation product pellet was separated from the supernatant $(10 \mathrm{mg})$ in order to be dialyzed by adding $5 \mathrm{ml}(2: 1)$ buffer A $(25$ $\mathrm{mM}$ Tris- $\mathrm{HCl}, \mathrm{pH} 8$ ) and dialyzed using $10 \mathrm{kDa}$ cut-off dialysis membrane. Dialysis membrane was included in $600 \mathrm{ml}$ of buffer B $(50 \mathrm{mM}$ Tris- $\mathrm{HCl}$, $\mathrm{pH} 8)$ and rested for $24 \mathrm{~h}$ in hotplate stirrers $\left( \pm 5^{\circ} \mathrm{C}\right)$, in addition, the buffer was also replaced every $8 \mathrm{~h}$ (Gegeckas et al., 2014).

\section{Purification of keratinase}

The dialysis result was purified by Sephadex G-50 filtration gel chromatography, which ranges from 1.5 to $30 \mathrm{kDa}$ (Sigma-Aldrich). The filtration gel was pre-equilibrated using Tris-HCl $25 \mathrm{mM}$ buffer, $\mathrm{pH}$ 8. The samples were inserted into the gel slowly then eluted by Tris- $\mathrm{HCl} 25 \mathrm{mM}$ buffer with $\mathrm{pH} 8$ to separate the protein and stop it at the $13^{\text {th }}$ fraction. Each fraction contains $1 \mathrm{ml}$ of readymade purified solution used for subsequent analysis.

\section{Keratinase assay}

The assay was performed as previously described (Sahoo et al., 2012) with some modifications. The keratinase activity was assayed with keratin (feather powder) as a substrate (Microbiology Laboratory, Universitas Sumatera Utara). Four milligram (0.004 $\mathrm{g}$ ) of keratin powder was dissolves in $1 \mathrm{ml}$ of $50 \mathrm{mM}$ Tris- $\mathrm{HCl}, \mathrm{pH} 8.0$ used as substrate. Two hundred fifty microliters of substrate was added to $500 \mu \mathrm{l}$ of enzyme solution with $250 \mu \mathrm{l} 50 \mathrm{mM}$ Tris- $\mathrm{HCl}$ buffer $\mathrm{pH} 7.8$ and was incubated for $30 \mathrm{~min}$ at $40^{\circ} \mathrm{C}$ in a waterbath. The reaction was terminated with $1 \mathrm{ml}$ $10 \%$ trichloroacetic acid and incubated at $4{ }^{\circ} \mathrm{C}$ for $10 \mathrm{~min}$. Then, the reaction mixture was centrifuged at $10,000 \times \mathrm{g}$ for $10 \mathrm{~min}$, and the supernatant was used to measure the absorbance at $280 \mathrm{~nm}$ against a reagent blank using spectrophotometer. Tyrosine solution (50-500 $\mu \mathrm{g} \mathrm{ml}^{-1}$ ) was used for standard curve. One unit of keratinase activity was defined as the volume of enzyme which increases the absorbance of 0.01 at a wavelength of $280 \mathrm{~nm}$.

\section{Estimation of protein concentration}

The protein concentration was essayed using a Bradford reagent. The composition of Bradford stock solution was $70 \mathrm{mg}$ Coomassie blue G-250 (Sigma-Aldrich), $20 \mathrm{ml} \mathrm{95 \%} \mathrm{ethanol,} 40 \mathrm{ml} \mathrm{85 \%}$ phosphoric acid homogenized with a magnetic stirrer, then filtered using Whatman qualitative filter. The Bradford reagent was prepared with a $425 \mathrm{ml}$ distilled water, $20 \mathrm{ml} \mathrm{95 \%}$ ethanol, $40 \mathrm{ml}$
$85 \%$ phosphoric acid added by $30 \mathrm{ml}$ Bradford stock solution homogenized with the magnetic stirrer, then filtered using Whatman qualitative filter. Protein content of keratinase was estimated using Bradford method (Bradford, 1976). Estimation of purified keratinase were based on SDS-PAGE visualization.

\section{SDS PAGE and Zymography}

Zymogram used a $10 \%$ separating gel with the addition of $0.2 \%$ keratin powder (chicken feathers). After the separation process, the gel was incubated in $2.5 \%$ Triton $^{\circledR} \mathrm{X}-100$ at $37^{\circ} \mathrm{C}$ for $1 \mathrm{~h}$. The gel was incubated in a $50 \mathrm{mM}$ Tris- $\mathrm{HCl}$ buffer (pH 8) overnight. Gel was stained in $0.05 \%$ using Coomassie Brilliant Blue for $2 \mathrm{~h}$. The last stage was to remove the remaining using coomassie ${ }^{\circledR}$ brilliant blue R-250 with the destaining solution until a white band appears.

\section{Scanning electron microscopy (SEM) analysis of degradation products}

Whole chicken feathers were degraded by keratinase strain B6 after the incubation of 48-96 h $\left(37^{\circ} \mathrm{C}, 180 \mathrm{rpm}\right)$. The controlled chicken feathers were cut into small pieces $( \pm 1 \mathrm{~cm})$ and added with $2 \%$ coccodylate buffer. The fixation solution was removed, added by coccodylate and $1 \%$ tetratoxide and soaked for $1 \mathrm{~h}$. The tetraoxide solution was removed and ethanol solution was given concentration levels of $70 \%, 80 \%, 90 \%$ and absolute ethanol. Solution was discarded and added by butanol. The sample piece of Au-coated metal was placed at the sample location in SEM (JEOL JSM-5310 LV, Japan) and tube was put into vacuum (0 Pa).

\section{Fourier transform infrared spectroscopy (FTIR)}

Fourier transform infrared spectroscopy (FTIR) analysis was performed to find out the peak amino acid chicken feather degradation keratinase B6 after the incubation of $96 \mathrm{~h}$. Fourier transform infrared spectroscopy (FTIR) analysis was based on the Wojciechowska method (Wojciechowska et al., 2004) with a slight modification. An IR spectroscopic analysis was performed using the FTIR 8201 PC, Shimadzu.

\section{Profile of amino acids}

Amino acid profilling was performed to observe the degraded product of keratin. The strain B6 was grown in the optimal feather medium for 5 days and the culture supernatant was obtained by centrifugation at $10.000 \times \mathrm{g}$ for $15 \mathrm{~min}$. The quantity of amino acid was determined using a highperformance liquid chromatography (Waters Corporation USA), the column used was Pico tag 3.9 x $150 \mu \mathrm{m}$, UV wavelength detector set at $256 \mathrm{~nm}$. 


\section{RESULTS AND DISCUSSION}

\section{Degradation of chicken feather waste}

Chicken feather is a keratin substrate, which can activate keratinase produced by Stenotrophomonas maltophilia B6. Keratin is the only source of $\mathrm{C}$ and $\mathrm{N}$ for keratinase secretion. The formation of a clear zone around the colonies of strain B6 on NB agar and skim milk gave initial information on extracellular keratinase activity (Figure 1A). Figure $1 \mathrm{~B}$ shows that biodegradation of chicken feathers occurred maximally after the treatment with B6 for $96 \mathrm{~h}$ of incubation at incubator shaker $(180 \mathrm{rpm})$ at $40^{\circ} \mathrm{C}$. Strain B6 was successfully isolated from landfill which effectively degrades chicken feather waste in moderate temperature. This is closely related to the temperature condition of the habitat of the isolation source. Native keratinase Stenotrophomonas maltophilia has various roles, such as reducing hexavalant chromium (Bhange et al., 2016), nematocidal activity (Jankiewicz et al., 2016), and plant growth-promoting activity (Jeong et al., 2010).

\section{Optimization on carbon and nitrogen source of fermentation medium}

The induction of carbon and nitrogen sources into the growth media greatly affects the production of keratinase by bacteria. Strain B6 utilizes chicken feathers as a major source of carbon and nitrogen for the continuity of cell growth. The addition of carbon and nitrogen sources was used as an additive to accelerate the continuity of cell division of strain B6. Great carbon supplementation affects the quantity of keratinase production (Figure 2A). Significantly, the keratinase activity increased up to $67.41 \pm 1.1 \mathrm{U} \mathrm{mL}^{-1}$ after the addition of sucrose to the media and culturing for 4 days. Glucose carbon sources were easily digestible by the bacteria because of their nature as monosaccharides. Meanwhile, the provision of other carbon sources can also increase the keratinase activity when it was compared to control. Sucrose has a positive influence on increased keratinase activity of Thermoactinomyces sp. YT06 (Wang et al., 2017).

The provision of nitrogen sources may also affect the effectiveness of keratinase as an indicator of keratinase activity shown in Figure 2B. Peptone was able to increase keratinase activity by $90.24 \mathrm{U}$ $\mathrm{mL}^{-1}$ after $96 \mathrm{~h}$ of incubation. In addition, $\mathrm{NaNO}_{3}$ and casein $\left(88.50 \mathrm{U} \mathrm{mL}^{-1} \pm 0.61\right.$ and $88.49 \pm 0.51 \mathrm{U}$ $\mathrm{mL}^{-1}$ ) also contributed in increasing the keratinase activity in our experiments. This result was the first report for Stenotrophomonas maltophilia that increased the keratinase activity by peptone which was previously reported for keratinase activity in Bacillus thuringiensis TS2 $\left(197.60 \pm 3.15 \mathrm{U} \mathrm{mL}^{-1}\right)$ (Sivakumar et al., 2012). Incubation of $96 \mathrm{~h}$ is the best time to increase the keratinase activity of strain B6.

\section{Growth of strain B6 and soluble protein}

The observation of bacterial cell growth and total dissolved protein in the treatment of glucose and

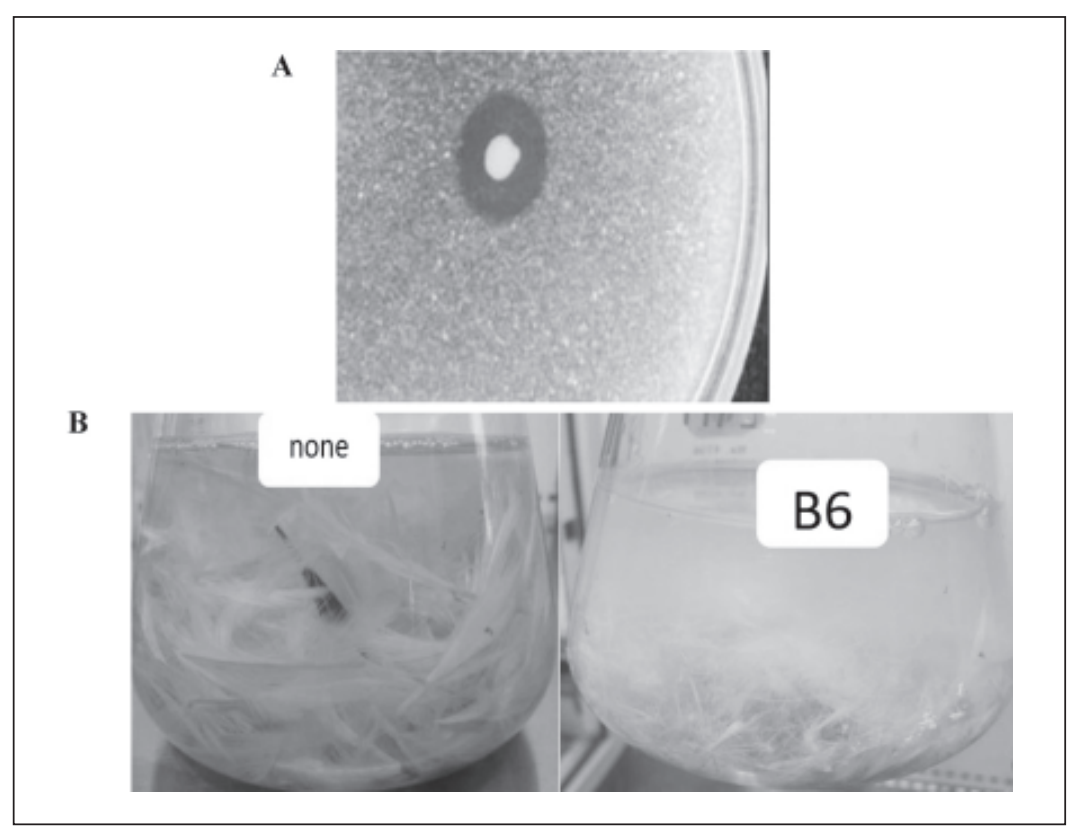

Fig. 1. The degradation process of chicken feathers by the strain B6 for 96 hours of incubation. (A) The formation of clear zone around the colonies of strain B6 which were grown on skim milk agar at $40^{\circ} \mathrm{C}$ for 24 hours. (B) The result of treatment comparison toward the chicken feathers with and without giving the B6 strain bacteria after $96 \mathrm{hr}$. 


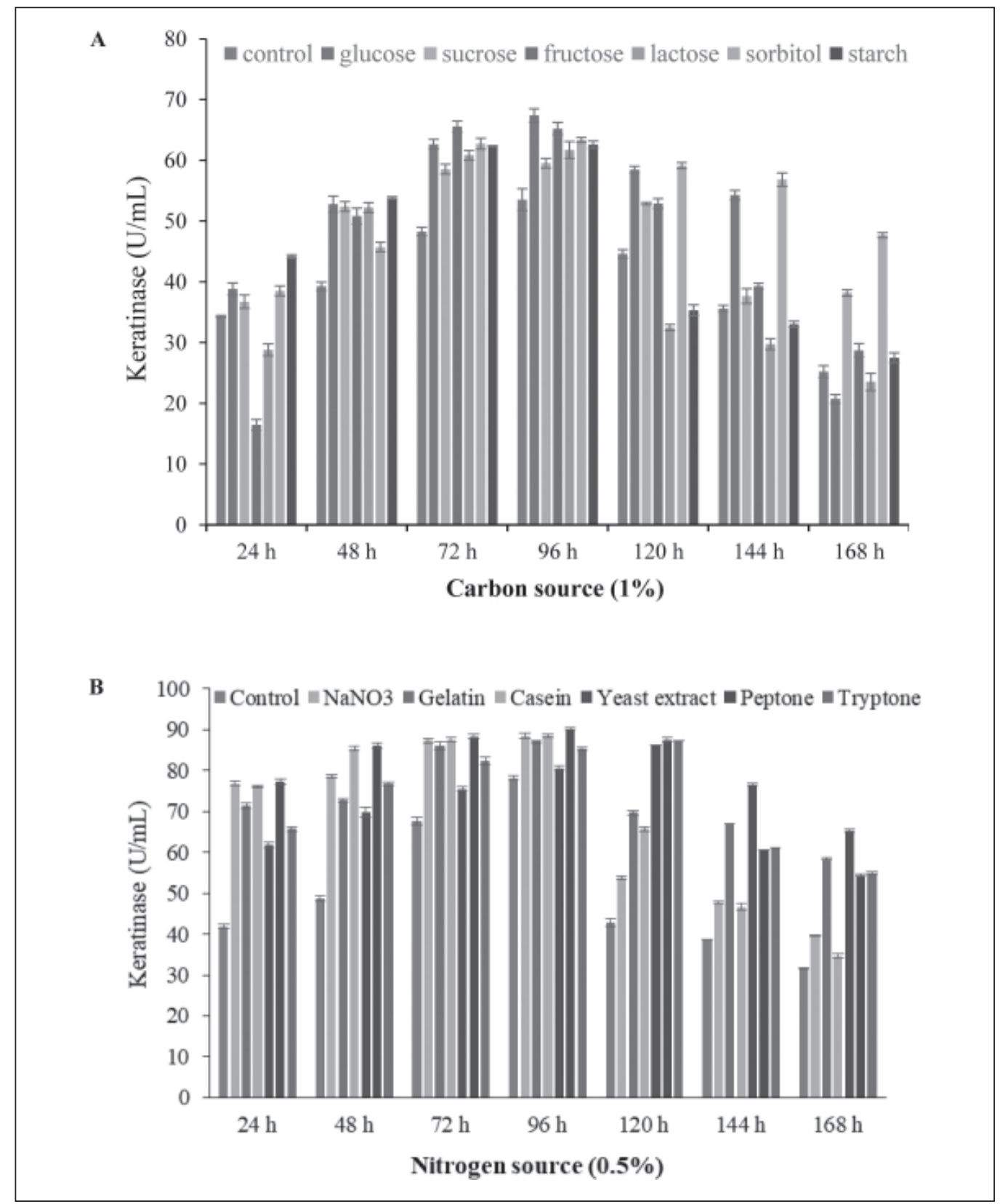

Fig. 2. Relative activity of strain B6 supplementation with different carbon and nitrogen sources. (A) Influence of carbon source. (B) Influence of nitrogen source. Values represent the mean \pm SD of three replicates.

peptone after $96 \mathrm{~h}$ of incubation was also performed. The results shown that the addition of glucose and peptone treatment helps the growth of bacterial cells more rapidly which is sufficient for quorum as an initiation to increase keratinase production. The bacterial cell at $96 \mathrm{~h}$ reached $4.22 \times 10^{8}$ cells $\mathrm{mL}^{-1}$ (Figure $3 \mathrm{~A}$ ) and the soluble proteins reached 67.96 $\mathrm{mg} \mathrm{mL}^{-1}$ (Figure 3B) on the treatment of glucose as a carbon source. Meanwhile, the number of bacterial cells of $5.49 \times 10^{8}$ (Figure $3 \mathrm{C}$ ) and the soluble proteins of $93.36 \mathrm{mg} \mathrm{mL}^{-1}$ (Figure 3D) was treated after the addition of peptone. The relevance of increased keratinase activity to soluble proteins has been demonstrated in this study.
Table 1 shows that the total free amino acid concentration in the culture filtrate was $2.2569 \mathrm{mg}$ $\mathrm{mL}^{-1}$ after the degradation of $96 \mathrm{~h}$. Alanine, serine, threonine and tyrosine were the mostly found amino acids during B6 hydrolysis supernatant result. Biotechnological applications consider the use of keratin degrading microorganisms or keratinase enzymes in the production of amino acids and peptides. Moreover, amino acids resulting from the utilization of feather or keratin-containing materials are one important product that can promote several industries such as animal feed and bio-fertilizer. Amino acids released during the biodegradation of feather by the host. 

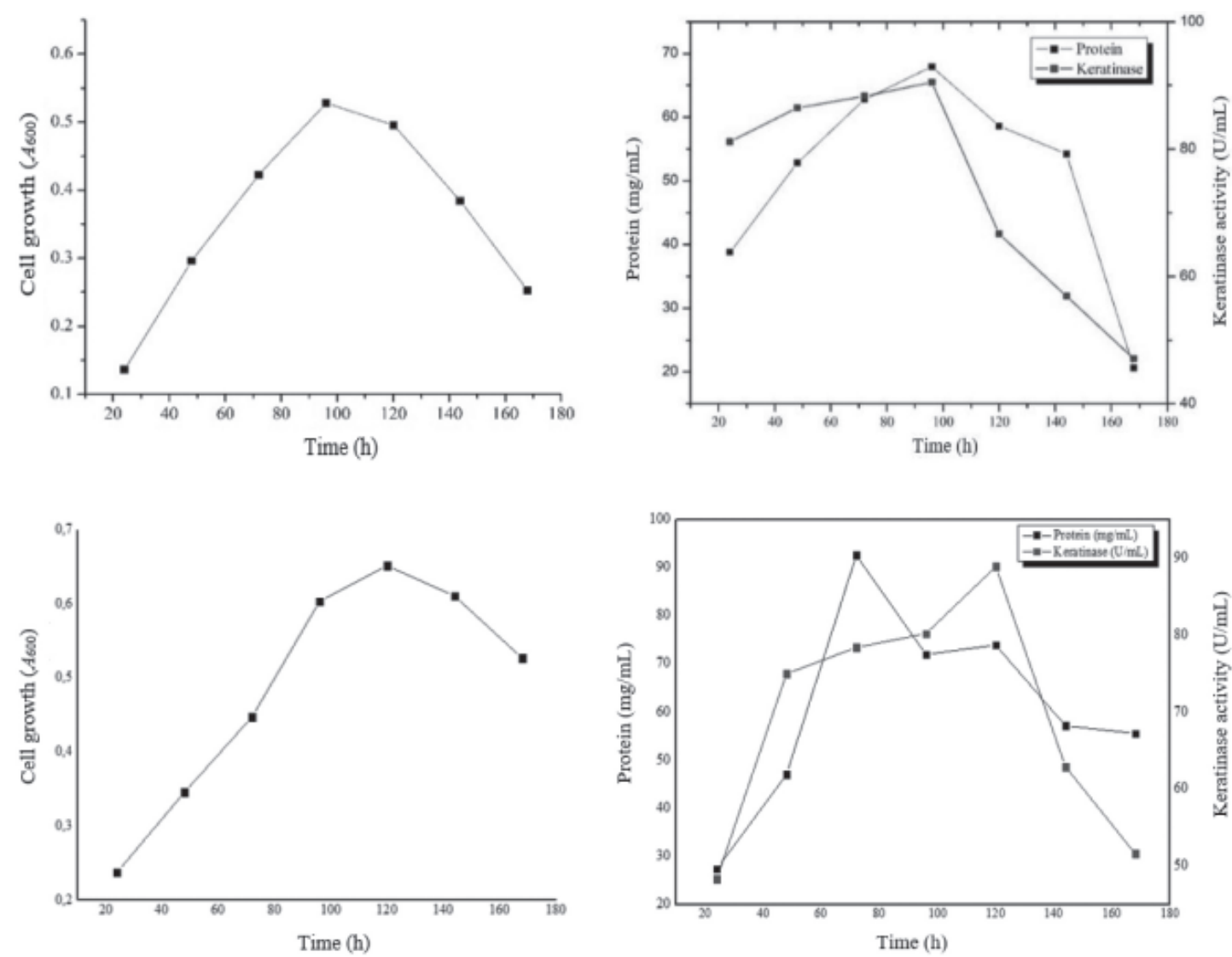

Fig. 3. The growth of bacterial cells and soluble proteins during the addition of the glucose and peptone. (A) The growth of bacteria which is enriched glucose $1 \%(\mathrm{w} / \mathrm{v})$. (B) Soluble proteins and the activity of keratinase after the addition glucose $1 \%$ $(\mathrm{w} / \mathrm{v})$. (C) The growth of bacteria which is enriched peptone $0.5 \%(\mathrm{w} / \mathrm{v})$. (D) Soluble proteins and the activity of keratinase after the addition peptone $0.5 \%(\mathrm{w} / \mathrm{v})$.

Table 1. Monitoring the level of amino acids in the cellfree supernatant of strain B6 at day 4 of cultivation

\begin{tabular}{lc}
\hline Amino acids & Concentration $\left(\mathrm{mg}^{\mathrm{mL}-1}\right)$ \\
\hline Glycine & 0.1207 \\
Alanine & 0.3387 \\
Arginine & 0.1664 \\
Aspartic acid & 0.0993 \\
Glutamic acid & 0.0941 \\
Phenylalanine & 0.0352 \\
Histidine & 0.0408 \\
Isoleucine & 0.0378 \\
Leucine & 0.0678 \\
Lysine & 0.1563 \\
Methionine & 0.0128 \\
Proline & 0.1716 \\
Serine & 0.2493 \\
Cysteine & 0.0484 \\
Threonin & 0.2393 \\
Tyrosine & 0.2228 \\
Valine & 0.1556 \\
Total & 2.2569 \\
\hline
\end{tabular}

\section{Effect of metal ions to keratinolytic activity}

The keratinase activity of strain B6 is increased by ions $\mathrm{Ca}^{+}, \mathrm{Mg}^{+}, \mathrm{Na}^{+}, \mathrm{Co}^{+}$and $\mathrm{K}^{+}$, respectively $116 \%, 110 \%, 111 \%, 111 \%$ and $109 \%$ (Table 2). The keratinase activity of strain B6 decreases due to the administration of $10 \mathrm{mM} \mathrm{Mn}$ and $10 \mathrm{mM} \mathrm{Ba}^{+}$. The result of this test gives the consideration that $\mathrm{Co}^{+}$, $\mathrm{Mn}^{+}$and $\mathrm{Ba}^{+}$do not increase the keratinase activity of both bacteria. The conformation of enzyme structure and complex substrate enzyme becomes stable and maintained by the salts formed by the metal ions. Moreover, cation plays an important role in maintaining the thermal stability of the enzyme. Brandelli et al. (2010) stated that the presence of divalent metal ions such as $\mathrm{Ca}^{2+}, \mathrm{Mg}^{2+}$, and $\mathrm{Mn}^{2+}$ always stimulate the activity of keratinase protein. Keratinase of strain B6 was positively stimulated by $\mathrm{Ca}^{2+}$ and $\mathrm{Mg}^{2+}(10 \mathrm{mM})$ (Table 2). Metal ions can be used for the process of hydrolysis optimization of keratin waste as the additive for keratinase stabilization. This result was confirmed by the previous study where the addition of $\mathrm{Ca}^{2+}$ and $\mathrm{Mg}^{2+}$ in the production of keratinase media 
Table 2. The Effect of the Addition of several types of metal ions and inhibitor on the activity related to native keratinase strain $\mathrm{B} 6$

\begin{tabular}{lcc}
\hline \multirow{2}{*}{ Metal ions and Inhibitors } & \multicolumn{2}{c}{ Relative activity (\%) } \\
\cline { 2 - 3 } & $5 \mathrm{mM}$ & $10 \mathrm{mM}$ \\
\hline Control & 100 & 100 \\
$\mathrm{Ca}^{2+}$ & $111 \pm 0.7$ & $116 \pm 1.5$ \\
$\mathrm{Mg}^{2+}$ & $108 \pm 1.6$ & $110 \pm 1.5$ \\
$\mathrm{Ba}^{2+}$ & $111 \pm 1.3$ & $76 \pm 1.5$ \\
$\mathrm{Mn}^{2+}$ & $83 \pm 1.0$ & $78 \pm 1.0$ \\
$\mathrm{Co}^{2+}$ & $107 \pm 1.5$ & $111 \pm 2.0$ \\
$\mathrm{Na}^{+}$ & $101 \pm 1.0$ & $111 \pm 1.0$ \\
$\mathrm{~K}^{+}$ & $105 \pm 1.5$ & $109 \pm 1.5$ \\
$P$ Pepstatin A & $55 \pm 2.0$ & $16 \pm 1.0$ \\
$\mathrm{PMSF}$ & $56 \pm 2.0$ & $29 \pm 1.5$ \\
$\mathrm{DTT}$ & $55 \pm 1.5$ & $43 \pm 1.6$ \\
EDTA & $94 \pm 1.0$ & $114 \pm 1.6$ \\
$N$-toyl-L-lysine & $48 \pm 1.0$ & $31 \pm 1.5$ \\
bromoacetic acid & $42 \pm 1.5$ & $19 \pm 1.5$ \\
chymostatin microbial & $15 \pm 1.0$ & $11 \pm 1.5$ \\
lodoacetic acid & $52 \pm 1.0$ & $32 \pm 1.5$ \\
Benzamidine & $31 \pm 1.5$ & $18 \pm 1.6$ \\
Trypsin inhibitor & $73 \pm 2.0$ & $40 \pm 1.5$ \\
2-mercaptoethanol & $66 \pm 2.0$ & $14 \pm 1.0$ \\
\hline
\end{tabular}

increased their activity (Lateef et al., 2015; Tork et al., 2016).

Protease can be classified based on their sensitivity to various types of inhibitors (Rawlings et al., 2004). It is important to know the protease type of its keratinase of strain B6 and other enzymes involved in the keratin degradation. The treatment of inhibitor administration in both bacteria does not increase the keratinase activity, except the addition of $10 \mathrm{mM}$ EDTA that can stimulate the keratinase activity of strain B6 (110\%) (Table 2). From all of the tested inhibitors, PMSF actually inhibits the keratinase (Table 2). It shows that its keratinase was the serine protease. Bose et al. (2014), stated that the keratinase activity of Bacillus amyloliquefaciens was inhibited by $5 \mathrm{mM}$ PMSF. The keratinase activity is only $1.25 \%$, which indicates the production of serine protease. This research result shows that EDTA can give a positive effect on keratinase activity of both keratinase bacteria. Keratinase activity of Bacillus subtilis of $10 \mathrm{mM}$ EDTA can stimulate the keratinase activity up to $144.8 \%$ (Cai et al., 2008).
EDTA as the chelator activates the active site of reductase and optimally hydrolyses the disulphide bond in the keratin structure resulting in 10 times of the increase of hydrolysis. The presence of reductase disulphide was beneficial not only to catalyse the reduction of the disulphide bond (S-S) but also the secretion of disulphide bond, which contains protein (Rahayu et al., 2012). The formation of disulphide bond is inhibited by metal complex ion EDTA (Trivedi et al., 2009). This result indicates that strain B6 produces other enzyme to degrade keratin namely disulphide reductase.

\section{Purification of keratinase}

The keratinase SmB6KER was purified by ammonium sulfate fractionation followed by dialysis membrane $(10 \mathrm{kDa})$ and Sephadex G-50 (Table 3 ). The purity of protein was analyzed by SDS-PAGE and keratinase activity was determined by zymogram after SDS-PAGE using keratin from chicken feathers as the substrate. Dialysis membrane resulted in 6.24 fold purification with a $63.64 \%$ recovery rate. After Sephadex G-50 chromatography, the purification was 19.18 fold with a final recovery to $35.61 \%$ and $397.52 \mathrm{U} / \mathrm{mg}$ of specific activity. The molecular mass of this purified SmB6KER was determined to be $26 \mathrm{kDa}$ by SDS-PAGE (Figure 4). An activity gel analysis confirmed that the purified SmB6KER was a single monomeric protein. Molecular mass of keratinase ranged from 18 to 240 $\mathrm{kDa}$ (Brandelli et al., 2010), $80 \mathrm{kDa}$ (Bacillus cereus), $26 \mathrm{kDa}$ (Bacillus licheniformis), $30 \mathrm{kDa}$ (Bacillus megaterium), $36 \mathrm{kDa}$ (Stenotrophomonas maltophilia N4) (Akhtar \& Edwards, 1997), $36 \mathrm{kDa}$ (Stenotrophomonas maltophilia DHHJ) (Gupta \& Ramnani, 2006), 130 kDa (Fervidobacterum pennavorans) (Friedrich \& Antranikian, 1996). We successfully reported that Stenotrophomonas maltophilia $\mathrm{B} 6$ has protein keratinase molecular mass of $26 \mathrm{kDa}$, which previously has never been reported.

\section{SEM analysis of degradation product}

SEM visualization shows that the degradation of chicken feathers by strain B6 occurred after $96 \mathrm{~h}$ of incubation (Figure 5). Feather barbicels were completely degraded by strain B6, also the length

Table 3. Purification profile of Keratinase from strain B6

\begin{tabular}{|c|c|c|c|c|c|}
\hline Purification steps & $\begin{array}{c}\text { Total activity } \\
\text { (U) }\end{array}$ & $\begin{array}{l}\text { Total protein } \\
(\mathrm{mg})\end{array}$ & $\begin{array}{l}\text { Specific activity } \\
(\mathrm{U} / \mathrm{mg})\end{array}$ & $\begin{array}{l}\text { Purification } \\
\quad \text { (fold) }\end{array}$ & $\begin{array}{l}\text { Yield } \\
(\%)\end{array}$ \\
\hline Concentrated Supernatant & 12648 & 610.20 & 20.73 & 1 & 100 \\
\hline Ammonium Sulphate $70 \%$ & 10380 & 303.94 & 34.15 & 1.65 & 82.07 \\
\hline Dialysis & 8050 & 62.18 & 129.46 & 6.24 & 63.64 \\
\hline Sephadex G-50 & 4504 & 11.33 & 397.52 & 19.18 & 35.61 \\
\hline
\end{tabular}




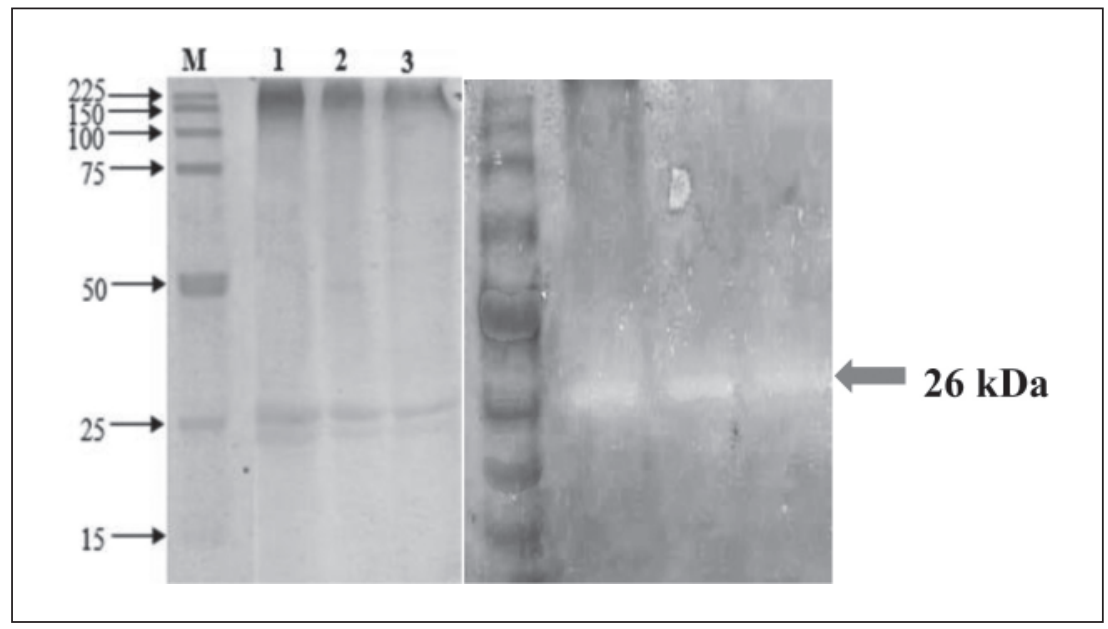

Fig. 4. SDS-PAGE and zymogram analysis of keratinase secreted by strain B6. (M) 10-225 kDa Protein Marker, (1) Precipitation of ammonium sulfate 70\% (2) $10 \mathrm{kDa}$ dialysis membrane (3) CM Sephadex G-50 chromatography. Arrows indicate the presence of protein bands.

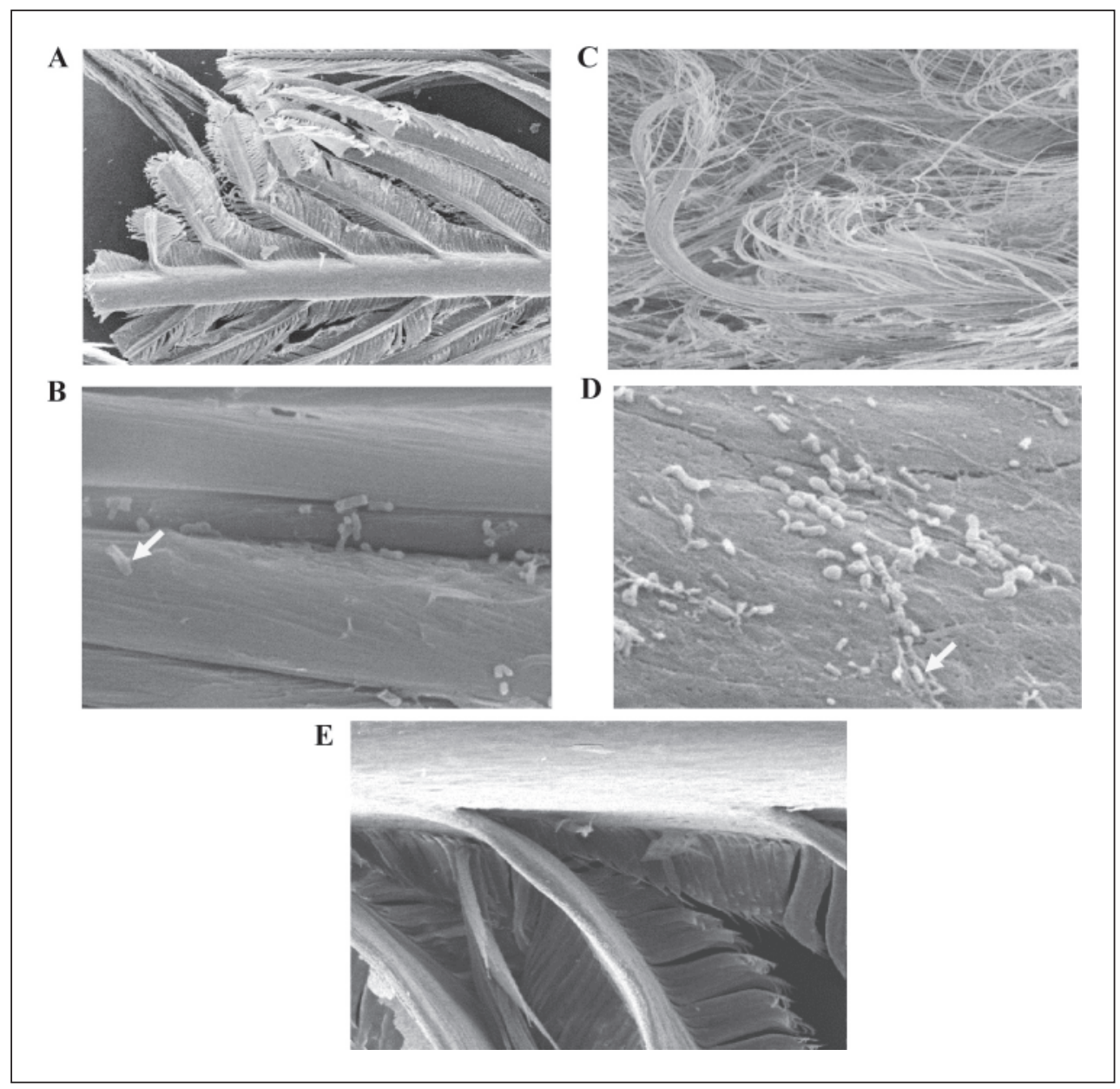

Fig. 5. Scanning electron micrographs of feather degradation by S. maltophilia B6. (A) The degradation of barb and barbules after 2 days; (B) The colonization of bacterial cells on feather surface after 2 days (yellow arrow); (C) The degradation of feather shaft after 4 days; (D) The colonization of bacterial cells on feather surface after 4 days (yellow arrow); (E) The uninoculated whole chicken feather and feather barbs. 


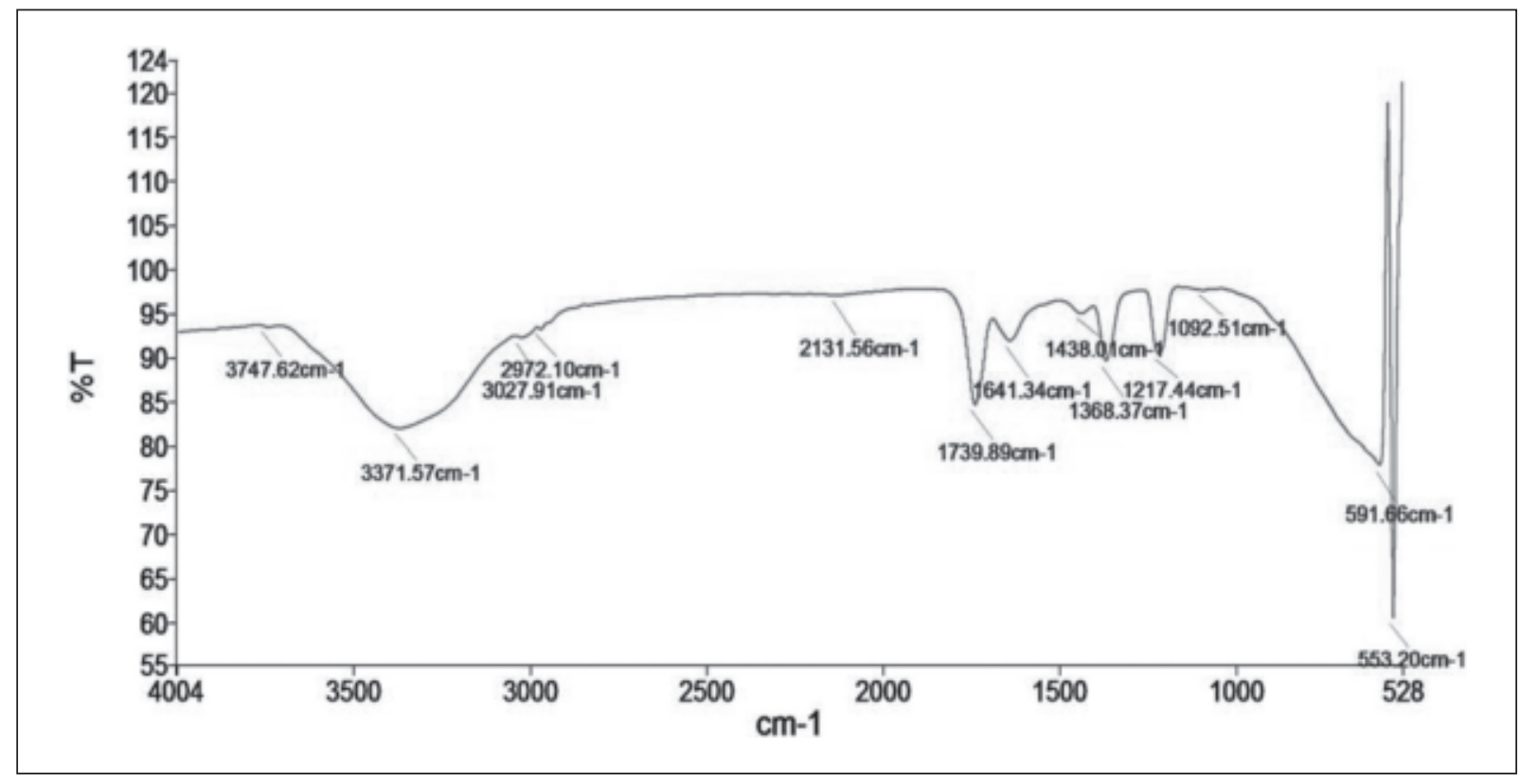

Fig. 6. IR spectra of degraded feathers. peak $3747 \mathrm{~cm}^{-1}(-\mathrm{OH})$; peak $2972 \mathrm{~cm}^{-1}$ (asymmetric $\left.-\mathrm{CH}_{3}\right)$; peak $1641 \mathrm{~cm}^{-1}$ (amide I); peak $1438 \mathrm{~cm}^{-1}$ (amide II); peak $1092 \mathrm{~cm}^{-1}(-\mathrm{C}-\mathrm{C}-)$; peak 523-553 $\mathrm{cm}^{-1}(-\mathrm{S}-\mathrm{S}-)$.

of the barbules and the width of the barbs were reduced (Figure 5C). The bacterial cells colonize on the surface of the chicken feather structure and cause the fiber structure to crack and disintegrate slowly (Figure 5D). This result was similar to the previous report that keratinase may damage the structure of the keratin substrate (Cedrola et al., 2012). Indirectly, chicken feathers were the only source of carbon and nitrogen for the growth of bacterial cells. This resulted was more convincing to use isolate B6 as a poultry feed additive. The abundance of chicken feather waste in the environment can be minimized through further research activities.

\section{FTIR analysis of degradation product}

The degradation of chicken feathers by strain B6 was confirmed using FTIR, keratin structure group was seen after the presence of peak spectrum FTIR is detected. FTIR spectra of degraded feather displayed that transmittance peaks nearby 523,553 , 1092, 1217, 1368, 1438, 1641, 1739, 2131, 2972, 3027,3371 and $3747 \mathrm{~cm}^{-1}$. The peak located in the range of $2700-3100 \mathrm{~cm}^{-1}$ indicating that the presence of $\mathrm{CH}$ groups, and the broad peak around $3747 \mathrm{~cm}^{-1}$ was usually caused by the vibration of hydrogen bonded -OH groups (Akhtar \& Edwards, 1997). The transmittance peak for the amideI (1650 $\left.\mathrm{cm}^{-1}\right)$ and amideII $\left(1547 \mathrm{~cm}^{-1}\right)$ suggests that there was a presence of $\alpha$-helix structure in the sample, moreover the amideI $\left(1638 \mathrm{~cm}^{-1}\right)$ and amideII $(1515$ $\mathrm{cm}^{-1}$ ) indicate the presence of a $\beta$-sheet type (Wojciechowska et al., 2004). The peak near 1100 $\mathrm{cm} \mathrm{cm}^{-1}$ was observed, and this fact indicates that
$\mathrm{C}-\mathrm{C}$ groups presents in each of the two samples (Wojciechowska et al., 2004).

Figure 4 showed the chicken feathers incubated by adding culture strain B6 resulted in the peaks of disulphide bonds become weak. Disulphide bonds owing to the $\mathrm{S}-\mathrm{S}$ stretching vibrations show a peak in the 500-550 $\mathrm{cm}^{-1}$ (Wojciechowska et al., 2004; Wojciechowska et al., 2002). The peaks appear in the range of 523-553 $\mathrm{cm}^{-1}$ as shown in Figure 6, which represents disulphide bonds present in the sample. The cysteine composition $(8.85 \%)$ on chicken feathers contributes to thiol structural element (SH) (Lee et al., 2015). Therefore, keratinase bacteria need to be utilized to hydrolyze the bond. Our experiment successfully reported that molecular mass of protein keratinase by strain B6. Stenotrophomonas maltophilia B6 has protein keratinase molecular mass of $26 \mathrm{kDa}$. This new isolated strain possesses high keratinase activity and is very effective in feather degradation, presenting potential use for biotechnological processes involving keratin hydrolysis.

\section{CONCLUSION}

In conclusion, optimization and characterization of a newly bacterial isolate, Strenotrophomonas maltophilia B6 (SmB6KER) has successfully enhanced the keratinolytic activity. The addition of glucose for $1 \%$ as the source of carbon is the best treatment in order to increase the keratinase's activity by $67.41 \pm 1.1 \mathrm{U} \mathrm{mL}^{-1}$, while the best source 
of nitrogen is pepton for $0.5 \%$ with yielded $90.24 \pm$ $0.7 \mathrm{U} \mathrm{mL}^{-1}$. SmB6KER belongs to serine protease family since its relative activity is inhibited by 10 $\mathrm{mM}$ of PMSF $(29 \pm 1.5 \%)$, but its relative activity back to increase after the addition of $10 \mathrm{mM}$ EDTA (114 \pm 1.6$)$, indicating that SmB6KER utilizes EDTA as chelating agent. SmB6KER has protein weight of $26 \mathrm{kDa}$ of molecular mass. The analysis result using SEM indicates that SmB6KER is able to degrade the chicken feathers after 96 hours of incubation. It is encouraged by the result of FTIR, which indicates that the disulfide bond (-S-S-) is in the peak range of $523-553 \mathrm{~cm}^{-1}$. The degradation of chicken feathers also produced $2.2569 \mathrm{mg} \mathrm{mL}^{-1}$ of amino acids from $40 \mathrm{~mL}$ fermentation medium. This result give significant idea that SmB6KER whose cell growth has been characterized and optimized can be used as excellent strain for the degradation process of chicken feathers substrate and synthesis product in the form of amino acid which further used as application aspect.

\section{ACKNOWLEDGEMENTS}

The authors would like to thank Department of Biology, Universitas Sumatera Utara and Research Centre for Biotechnology, Indonesian Institute of Science for supporting this research. This research was funded by DRPM, Republic of Indonesia under USU Contract \#136/UN5.2.3.1/PPM/KP-DRPM/ 2018 of Program Magister Menuju Doktor untuk Sarjana Unggul.

\section{REFERENCES}

Akhtar, W. \& Edwards, H.G.M. 1997. Fouriertransform raman spectroscopy of mammalian and avian keratotic biopolymers. Spectrochimica Acta Part A Molecular and Biomolecular Spectroscopy, 53A(1): 81-90.

Anitha, T.S. \& Palanivelu, P. 2012. Production and characterization of keratinolytic protease(s) from the fungus, Aspergillus parasiticus. International Journal of Research in Biological Sciences, 2(2): 87-93.

Bach, E., Cannavan, F.S., Duarte, F.R.S., Taffarel, J.A.S., Tsai, S.M. \& Brandelli, A. $2011 \mathrm{a}$. Characterization of feather-degrading bacteria from Brazilian soils. International Biodeterioration \& Biodegradation, 65(1): 102107.
Bach, E., Daroit, D.J., Correa, A.P.F. \& Brandelli, A. 2011b. Production and properties of keratinolytic proteases from three novel Gram-negative feather-degrading bacteria isolated from Brazilian soils. Biodegradation, 22(6): 11911201.

Bhange, K., Chaturvedi, V. \& Bhatt, R. 2016. Feather degradation potential of Stenotrophomonas maltophilia KB13 and feather protein hydrolysate $(\mathrm{FPH})$ mediated reduction of hexavalent chromium. 3 Biotechnology, 6(1): 41-49.

Bose, A., Pathan, S., Pathak, K. \& Keharia, H. 2014. Keratinolytic protease Production by Bacillus amyloliquefaciens 6B Using Feather Meal as Substrate and Application of Feather Hydrolysate as Organic Nitrogen Input for Agricultural Soil. Waste and Biomass Valorization, 5(4): 595-605.

Bradford, M.M. 1976. A rapid and sensitive method for the quantitation of microgram quantities of protein utilizing the principle of protein-dye binding. Analytical Biochemistry, 72(1-2): 248254.

Brandelli, A., Daroit, D.J. \& Riffel, A. 2010. Biochemical features of microbial keratinases and their production and applications. Applied Microbiology and Biotechnology, 85(6): 17351750.

Brandelli, A. 2008. Bacterial keratinases: useful enzymes for bioprocessing agroindustrial wastes and beyond. Food and Bioprocess Technology, 1(2): 105-116.

Cai, C., Chen, J., Jiong, J., Yin, Y. \& Zheng, X. 2008. Purification and characterization of keratinase from a new Bacillus subtilis strain. Journal of Zhejiang University SCIENCE B, 9(9): 713-720.

Cao, Z.J., Zhang, Q., Wei, D.K., Chen, L., Wang, J., Zhang, X.Q. \& Zhou, M.H. 2009. Characterization of a novel Stenotrophomonas isolate with high keratinase activity and purification of the enzyme, Journal of Industrial Microbiology 36(2):181-188.

Cedrola, S.M.L., de Melo, A.C.N. \& Mazotto, A.M. 2012. Keratinases and sulfide from Bacillus subtilis SLC to recycle feather waste. World Journal of Microbiology and Biotechnology, 28(3): 1259-1269.

Daroit, D.J., Correa, A.P.F. \& Brandelli, A. 2009. Keratinolytic potential of a novel Bacillus sp. P45 isolated from the Amazon basin fish Piaractus mesopotamicus. International Biodeterioration \& Biodegradation, 63(3): 358363. 
Fang, Z., Zhang, J., Liu, B., Du, G. \& Chen, J. 2013. Biochemical characterization of three keratinase enzymes from Stenotrophomonas maltophilia BBE11-1 for biodegrading keratin wastes. International Biodeterioration \& Biodegradation, 82: 166-172.

Friedrich, A.B. \& Antranikian G. 1996. Keratin Degradation by Fervidobacterium pennavorans, a novel thermophilic anaerobic species of the order thermotogales. Applied and Environmental Microbiology, 62(8): 2875-2882.

Gegeckas, A., Gudiukait, R. \& Citavicius, D. 2014. Keratinolytic proteinase from Bacillus thuringiensis AD-12, International Journal of Biological Macromolecules, 69: 46-51.

Gradisar, H., Friedrich, J., Krizaj, I. \& Jerala, R. 2005. Similarities and specificities of fungal keratinase proteases: comparison of keratinases of Paecilomyces marquandii and Doratomyces microsporus to some known proteases, Applied and Environmental Microbiology, 71(7): 34203426.

Gupta, R., Beg, Q.K. \& Lorenz, P. 2002. Bacterial alkaline proteases: molecular approaches and industrial applications. Applied Microbiology and Biotechnology, 59(1): 15-32.

Gupta, R. \& Ramnani, P. 2006. Microbial keratinases and their prospective applications: An overview. Applied Microbiology and Biotechnology, 70(1): 21-33.

Jankiewicz, U. \& Frąk, M. 2017. Identification and properties of a keratinase from Stenotrophomonas maltophilia N4 with potential application in biotechnology. Ecological Questions, 4: 15-24.

Jankiewicz, U., Larkowska, E. \& Swiontek, B.M. 2016. Production, characterization, gene cloning, and nematocidal activity of the extracellular protease from Stenotrophomonas maltophilia N4. Journal of Bioscience and Bioengineering, 121(6): 614-618.

Jeong, J.H., Lee, O.M., Jeon, Y.D., Kim, J.D. \& Lee, N.R. 2010. Production of keratinolytic enzyme by a newly isolated feather-degrading Stenotrophomonas maltophilia that produces plant growth-promoting activity. Process Biochemistry, 45(10):1738-1745.

Lateef, A., Adelere, I.A. \& Gueguim-Kana, E.B. 2015. Bacillus safensis LAU 13: a new source of keratinase and its multi-functional biocatalytic applications. Biotechnology \& Biotechnological Equipment, 29(1): 54-63.

Lee, Y.S., Phang, L., Ahmad, S.A. \& Ooi, P.T. 2015. Microwave-Alkali Treatment of Chicken Feathers for Protein Hydrolysate Production. Waste Biomass Valor, 7(5): 1147-1157.
Rahayu, S., Syah, D. \& Suhartono, M.T. 2012. Degradation of keratin by keratinase and disulfide reductase from Bacillus sp. MTS of Indonesian origin. Biocatalysis and Agricultural Biotechnology, 1(2): 152-158.

Rao, M.B., Tanksale, A.M., Ghatge, M.S. \& Deshpande, V.V. 1998. Molecular and biotechnological aspects of microbial proteases. Microbiology and Molecular Biology Reviews, 62: $597-635$.

Rawlings, N.D., Tolle, D.P. \& Barrett, A.J. 2004. MEROPS: the peptidase database. Nucleic Acids Research, 32: 160-164.

Revathi, K., Singh, S., Khan, A.M. \& Suneetha, V. 2013. A potential strain of keratinolytic bacteria VIT RSAS2 from Katpadi and its pharmacological benefit. International Journal of Pharmaceutical Sciences Review and Research, 20(2): 89-92.

Riffel, A. \& Brandelli, A. 2006. Keratinolytic bacteria isolated from feather waste. Brazilian Journal of Microbiology, 37(3): 395-399.

Sahoo, D.K., Das, A., Thatoi, H., Mondal, C. \& Mohapatra, P.K.D. 2012. Keratinase production and biodegradation of whole chicken feather keratin by a newly isolated bacterium under submerged fermentation. Applied Biochemistry and Biotechnology, 167(5): 1040-1051.

Sivakumar, T., Shakar, T., Vijayabaskar, P. \& Ramasubramanian, V. 2012. Optimization for keratinase enzyme production using Bacillus thuringiensis TS2. Academic Journal of Plant Sciences, 5(3): 102-109.

Sivakumar, T., Shankar, T. \& Ramasubramanian, V. 2012. Purification properties of Bacillus thuringiensis keratinase enzyme. AmericanEurasian Journal of Agricultural \& Environmental, 12(12): 1553-1557.

Suryanto, D., Walida, H., Nasution, S.K. \& Munir, E. 2017. Partial Characterization of Keratinase activity of Local Novel Bacteria Isolated from Feather Waste. Journal of Pure and Applied Microbiology, 11(1): 173-180.

Tork, S.E., Shahein, Y.E., El-Hakim, A.E., AbdelAty, A.M. \& Aly MM. 2016. Purification and partial characterization of serinemetallokeratinase from a newly isolated Bacillus pumilus NRC21. International Journal of Biological Macromolecules, 86: 189-196.

Tork, S.E., Shahein, Y.E., El-Hakim, A.E., AbdelAty, A.M. \& Aly, M.M. 2013. Production and characterization of thermostable metallokeratinase from newly isolated Bacillus subtilis NRC 3. International Journal of Biological Macromolecules, 55: 169-175. 
Trivedi, M.V., Laurence, J.S. \& Siahaan, T.J. 2009. The role of thiols and disulfides in protein chemical and physical stability. Current Protein \& Peptide Science, 10(6): 614-625.

Wang, L., Qian, Y., Cao, Y., Huang, Y., Chang, Z. \& Huang, H. 2017. Production and Characterization of Keratinolytic Proteases by a Chicken Feather-Degrading Thermophilic Strain, Thermoactinomyces sp.YT06. Journal of Microbiology and Biotechnology, 27(12): 2190-2198.

Wang, X. \& Parsons, C.M. 1997. Effect of processing systems on protein quality of feather meal and hair meal. Poultry Science, 76(3): 491-496.

Wojciechowska, E., Rom, M., Włochowicz, A., Wysocki, M. \& Birczynska. 2004. The use of Fourier transform-infrared (FTIR) and Raman spectroscopy (FTR) for the investigation of structural changes in wool bre keratin after enzymatic treatment, Journal of Molecular Structure, 704(1): 315-321.
Wojciechowska, E., Włochowicz, A., Wysocki, M., Pielesz, A. \& WesełuchaBirczynska, A. 2002. The application of Fourier-transform infrared (FTIR) and Raman spectroscopy (FTR) to the evaluation of structural changes in wool fibre keratin after deuterium exchange and modication by the orthosilicic acid. Journal of Molecular Structure, 614(1): 355-363.

Yamamura, S., Morita, Y., Hasan, Q., Yokoyama, K. \& Tamiya, E. 2002. Keratin degradation: a cooperative action of two enzymes from Stenotrophomonas sp. Biochemical and Biophysical Research Communications, 294(5): 1138-1143. 